\title{
Elu Sõna: päästmine, tervenemine ja edukus*
}

\section{$\underline{\text { Tuija Hovi }}$}

Nimetusega «uus usuliikumine» viidatakse sageli idamaistele, enamasti India päritoluga liikumistele, mis leidsid 1970.-80. aastail tee ka Põhjamaadesse - mingis amerikaniseerunud vormis hipiliikumise kiiluvees. Indiast pärinevate liikumiste ja muude New Age'i suundade kõrval pakutakse usu otsijaile ka arvukaid uusi kristlikke osaduskondi, kus piibellikku fundamentalismi $\underline{1}$ on vahelduvalt tõlgendatud (vt näiteks Junnonaho 1996: 33, 48). Soome traditsiooniliselt luterlikus õhkkonnas esindavad vabakristlikud äratusliikumised suurimat põhireligioonist eralduvat suunda.

Vabakristliku karismaatilisuse hulka kuulub näiteks Elämän Sana (Elu Sõna) kogudus, mille juured ulatuvad Ameerika nelipühikiri$\mathrm{ku}$ 1950. aastate äratuslainesse, nõndanimetatud tervendamisäratusse (healing revival). Ameerika nelipühikirikust mõjutusi ammutanud rootsi noorsoopastor Ulf Ekman rajas aastal 1983 Uppsalasse Livets Ord nimelise koguduse, mis on hiljem saanud kuulsaks tänu selle liikmeskonnaga ühinenud tuntud isikutele ning omandanud meedias küsitava maine usutervendamise, eksortsismi ja eriti raha tähtsuse rõhutamise tõttu (Gustavsson 1991: 213). Uppsala koguduses on praegu kokku paar tuhat liiget. Nelipühiliikumise juured

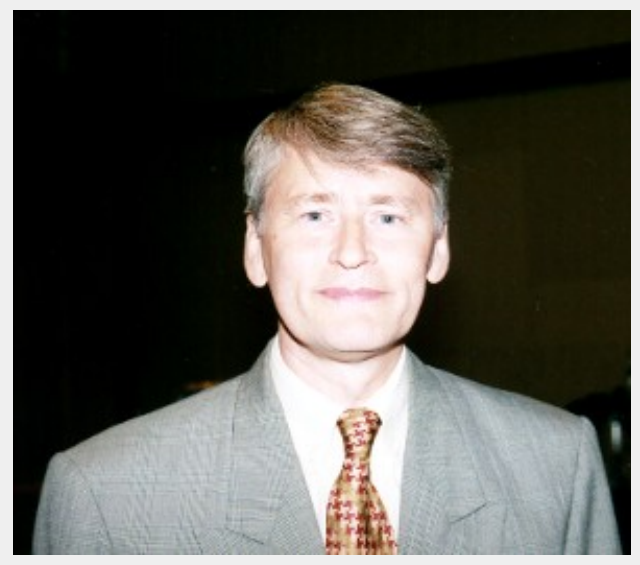

Johnny Foglander, Uppsala Elu Sõna koguduse õpetaja paistavad Elu Sõnas välja näiteks usklike ristimises vee alla vajutamise teel. Sellele lisaks peab usklik taotlema ristimist Pühas Vaimus. $\underline{\underline{2}}$ Koguduse liikmeiks võivad olla ainult usklikud (Heino 1997: 147).

Nendest eespool nimetatud joontest hoolimata ei saa Livets Ord'i (Elu Sõna) pidada nelipühiäratuse osaks, vaid ta kuulub sellest eraldunud äratusliikumisse, mida kutsutakse Usuliikumiseks (Heino 1997: 146). Õpetuse pearaskus on eriti vankumatu usu ja süstemaatilise piibliõpetuse rõhutamises, niisama kui omal ajal baptismis lansseeriti täiskasvanute ristimise ja nelipühiliikumises armuannete ideed tõsiusklike tunnusmärkideks (ES 2). Soomes on kogudused suhteliselt väikesed, kuid tegevus on siiski aktiivne ja värbamistööd tehakse pidevalt. Turus tegutsev Elämän Sana on Soome kohta suhteliselt suur Usuliikumise kogudus. Sellesse kuulub praegusel hetkel umbes 130 registreeritud liiget. Muid Usuliikumist esindavaid iseseisvaid kogudusi on arvukalt. Sellised on näiteks Helsingis tegutsevad Hyvät Uutiset (Head Sõnumid), Elävä Sana (Elav Sõna) ja Uskon Sana (Usu Sõna), mis kirjastab soomekeelset Usuliikumise kirjandust, samuti Tampere Võidu keskus ja Joensuu City-kogudus. Ka Soome läänerannikul, Pohjanmaal, on liikumisel poolehoidu ja tegevusvormiks on kohalikud palveringid. 
Öeldakse, et Elu Sõna esindab, nagu teisedki Usuliikumise osaduskonnad nn eduteoloogiat, õpetust sellest, kuidas kõik maised hüved, nagu rikkus ja tervis, on Jumala õnnistuse märgid - Jumala tahte järgimine viib automaatselt edule. Vastavalt viitab elus allamäge minek otseselt halvale jumalasuhtele ja Saatana tegutsemisele inimese meeles. Eduteoloogia juured ulatuvad Ameerika nelipühiäratuse ja karismaatilise liikumise kaudu reformeeritud kiriku tõlgenduseni, mille koha-

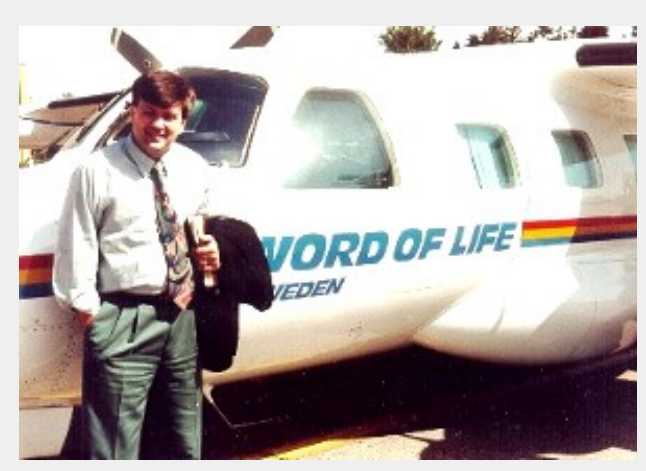

Carl-Gustaf Severin selt Jumala õnnistus avaldub uskliku elus peale vaimuliku õnnistuse ka ilmaliku edukusena (Heino 1997: 146). Elusõnalaste meelest on nimetusel «eduteoloogia» siiski pejoratiivne varjund, mis nende vaate kohaselt annab vale suuna kujutlusele koguduse põhimõtteist. Edutaotlust nii Elu Sõna kristliku õpetusena kui ka ajastuomase trendina profaanses kontekstis vaatlen artikli lõpus. Esmalt esitan ülevaate Usuliikumise ja Elu Sõna seostest ning kirjeldan selle järel Elu Sõna koguduse tegevust Soomes ning käsitlen ligemalt edukuse ideed.

\section{Ajalooline taust: tervendamisäratus}

Nagu eespool viidatud, on Usuliikumise juured Ameerika nelipühiäratuse tervendamisäratuses (healing revival). Elu Sõna õpetuses on tervenemise ja tervendamise teemad jätkuvalt esil. Tervenemise all mõistetakse nii füüsilist kui vaimset ja vaimulikkugi tervenemist ja paranemist. Vestlustes koguduse liikmetega tuleb tervenemise teema korduvalt esile nii isiklike tervenemisjutustustena kui kirjeldustena haigete eest palvetamisest. Näiteks olgu koguduse lehes avaldatud exemplum:

Enne jõule andis meie kogudus raadiosaateid otse koosolekult. Ühes saates sai meie pastor teadmissõnad, et kellelgi kuulajatest on südames rütmihäired. Saate ajal palvetati selle asja pärast. Järgmisel päeval helistas keegi naine ja jutustas, et tal oli nelja kuu jooksul südames olnud arsti poolt diagnoositud rütmihäire. Raadiosaadet kuulates ei tundnud ta veel midagi, kuid kui ta õhtul magama heitis, hakkas Jumala vägi voolama tema kehas, eriti vasakul pool. Tema rütmihäired lõppesid samal silmapilgul. Varsti pärast seda läks naine arstlikule kontrollile ja süda tunnistati täiesti terveks. Ta oli oma tervenemise eest Jumalale väga tänulik (Elu Sõna koguduse Uutislehti, kevad/suvi 1998).

Haigete eest palvetamine on üks tüüpilisematest ja arhailisematest kristlikest rituaalidest. Toimingus sisaldub mõte, et Jumal võib imepärasel viisil sekkuda inimese elu kulgu. Jumala abil tervendamise pärimus nii Ida kui Lääne kirikuis on pikk. ${ }^{3}$ Niisamuti on deemonite väljaajamine, eksortsismgi, olnud algusest peale kristliku mõtlemise ja toimimise osa. Karismaatilisse katoliiklusesse juba varemgi kuulunud imed said 19.- 20. sajandi vahetusel üldisteks ka protestantide hulgas (Harrell 1975: 10-11).

Vaimuliku elu süvenemine ja ekstaatilisus seostusid eriti 19. sajandi lõpu Ameerika Ühendriikides reformeeritud kiriku keskel puhkenud nelipühiäratusele eelnenud holiness-liikumisega. Selle liikmed olid seisukohal, et pöördumise järel on oluline jätkuv osadus Püha Vaimuga, mida representeeris võõraste keelte kõnelemine armu lõpliku väljendusena, mida iga kristlane pidi taotlema. Õpetati, et Püha Vaimu kogemine peaks olema jätkuv (Harrell 1975: 
11; Albanese 1992: 173-174). Keskseim õpetus nelipühiliikumises ongi just üleloomuliku püsiv võimalikkus ja tähtsus inimese elus Püha Vaimu jätkuvate manifestatsioonidena, selle asemel, et Püha Vaimuga ristimine oleks ainuke pöördumisjärgne vaimulik kogemus. Tähtsad on üheksa Piiblis nimetatud (1 Kr 12) Püha Vaimu armuandi, milleks on tarkuse sõnad, taibu sõnad, usu and, parandamise and, imetegude vägi, prohvetivõime, vaimude eristamise võime, võõraste keelte kõnelemise and ja keelte tõlgendamise and. Kõiki neid ande arvatakse olevat kristlastele kättesaadavad mitte ainult Piiblis kirjeldatud ajal, vaid jätkuvalt. Usutakse, et neil, kel on karismaatilisi ande, on ka väge ehitada teiste usku (Harrell 1975: 1112). Nagu eespool olevast tervenemisjutustki võib märgata, on nelipühiäratuse poolt esile tõstetud armuannid ka Elu Sõnas aktiivselt kasutusel.

Evangeelse protestantluse karismaatiline äratus arenes nimelt väikestes nelipühikirikutes. Karismaatiliste evangelistide tervendamisäratuse (healing revival) võib paigutada II maailmasõja järgsetesse aastatesse 1947-1958. Kõige säravamad jutlustajad vabastasid ennast peagi kirikute mõjuvõimust ja hakkasid tegutsema iseseisvalt, rändevangelistidena. ${ }^{4}$ Karismaatilised evangelistid võtsid eeskuju teistest, varasemate äratusliikumiste esindajatest. Paljudele oli eeskujuks juba varakult rohket poolehoidu leidnud evangelist Billy Graham $\underline{\underline{5}}$ (Harrell 1975: 5). Tervendamisäratuse evangelistid ei esindanud tegelikult Grahamiga sedasama äratuse suunda. Kuigi pattudest päästmist, Püha Vaimu armuande ja nelipühiliikumisele tüüpilist rõõmu jutlustati, polnud see keskne sõnum. Olulisim oli Püha Vaimu ime, see, et Vaim tervendas haigeid ja äratas surnuid üles. Koosolekuid peeti üle maa suurtes telkides ja saalides. Evangelistidel oli mitmesuguseid individuaalseid tervendamistehnikaid, ja kõige edukamad neist olid hiilgavad esinejad, kes suutsid köita külastajate huvi tundide kaupa (Harrell 1975: 6). Kui nelipühiliikumine hakkas saavutama massievangeliseerimise suurusjärku, oli ta piisavalt tugev liikumine laskmaks endasse ka mõningaid õpetuslikke erinevusi. Suurim nelipühiäratus oli alanud «viimaste aegade õnnistuste» prohveteerimisega (latter rain), milles kuulutati õpetust Püha Vaimu armuandidest. Äratus laienes kogu maailma hõlmavaks ja 1950. aastad olid ka Soome nelipühiliikumise jaoks jõuliselt ekspansiivne aeg (Harrell 1975: 20; Holm 1978: 24).

Karismaatilise äratuse soosing hakkas Ameerikas vaibuma aastal 1958. Üldsus väsis, sest imed olid saanud liiga tavapärasteks, nõudmised liiga uskumatuteks, prohveteid oli liiga palju ja liikumist hakati süüdistama pettustes ja liialdustes (Harrell 1975: 7).6 Hiljem suundus huvi kõigile Püha Vaimu andidele, mitte üksnes tervendamisele, ja liikumine mitmekesistus. Kampaaniad muutusid stereotüüpsemaiks, lavastatumaiks ja professionaalsemalt korraldatuiks. Koosolekud siirdusid peentesse hotellidesse ja lugupeetud kirikutesse ning äratuskoosolekud asendusid karismaatiliste konverentside ja seminaridega (Harrell 1975: 8-9). Näiteks aastail 1956-1966 said laialdase tähelepanu osaliseks Derek Prince'i juhitud tunnistamiskoosolekud (testimony revival). Tunnistati enda kogetud imesid, oma pöördumisi, tervenemisi ja muid vaimulikke imesid, mida toitis üha kasvav hulk karismaatilisi jutlustajaid ja ilmikuid (Harrell 1975: 180).

Jõuliselt laienev äratus vajas õpetajaid, sest tekkis vajadus analüüsida karismaatilist õpetust kristliku teoloogia traditsiooni valgusel. Ainult vähesed tegutsevaist jutlustajaist olid selle jaoks piisavalt haritud. Oli avatud võimalus uut laadi süstemaatilise õpetuse jaoks. Varsti hakkaski ilmuma ajakirju, milles loodi äratusele teoloogiat (Harrell 1975: 181-183). Tervendamisäratus oli niisiis jõudnud punkti, kus ta pidi suutma tõhusamalt organiseeruda, võimaks jätkuda. Pelgalt karismaatiliste juhtisikute varal pole usulisel liikumisel kestvust. Institutsionaliseerumine loob liikumisele struktuuri, millega selle väärtusi ja eesmärke saab 
organiseeritult teostada. See võimaldab põhimõtteid efektiivselt levitada ja reformid või äratused on nimelt olukorra tüüpnäited (McGuire 1981: 132-133).

Organiseerumisvajadusele reageeris esimesena algselt baptistijutlustajana ja õpetajana tegutsenud Kenneth E. Hagin. 1962. aastal rajas Hagin oma ühenduse Oklahoma osariiki Tulsasse, koordineerimaks laienevat evangeliseerimistegevust. Ta ise toimis taevaste nägemustega prohvetina, nägemuste juhatusel sai ta pastoriks. Hagin korraldas kogu maal hotellides õpetamiskoosolekuid ja teenis hästi, levitas kirjandust ja helilinte, rääkis raadios ja avaldas kord kuus ilmuvat ajakirja The Word of Faith, mida on praegu võimalik lugeda ka on-line-vormis (Harrell 1975: 186; http://www.rhema.org/wof.htm [viidatud 7.9.1998]). Aastast 1966 Oklahoma Tulsas tegutsenud Kenneth Hagin Ministries on ulatuslik koolitus- ja infoorganisatsioon campus-aladega ja tervendamiskeskustega. Aastast 1974 on seal tegutsenud ka piiblikool, Rhema Bible Training School (http: \www.rhema.org/wof.htm [viidatud 7.9. 1998]). Haginiga sarnased õpetuse vormijad on muuhulgas olnud temast veelgi tuntum evangelist Benny Hinn ja Paul Crouch, kes levitab Usuliikumise sõnumit Trinity Broadcasting Networki kaudu (Christianity Today 37: 14, 1993).

\section{Õpetuslikud põhimõtted}

Usuliikumise Põhjamaadesse toonud ja Livets Ord'i rajanud Ulf Ekman tegutses 1970. aastail luterliku noorsoopastorina. Ta läks oma äia, metodistipastor Sten Nilssoni õhutusel Ühendriikidesse, Kenneth E. Hagini piiblikooli Tulsas. Sealt saadud muljetest julgustatuna alustas Ekman vastava piiblikooliga Uppsalas, rajades sinna koguduse. Piiblikooli tuli kohe ligi 200 õpilast peamiselt Põhjamaadest (ES 3).

Piiblikooli mõtteks on anda usklikele ühtne ja süstemaatiline õpetus «piibellikust tõest». Kes tahes piiblikoolis käinutest on kindlasti võimeline vastama kõikidele teoloogilistele küsimustele ja evangeliseerima (ES 2, ES 4: 34; ES 9; ES 10). Õpetuse lähtekohaks on päästetud saamine ehk isiklik usuline otsustus, pöördumine. See idee kulmineerub Piibli Johannese evangeeliumis kirjeldatud Jeesuse ja Nikodeemuse vestluses uuestisündimisest ja usust (Jh 3: 1-21; TKU/A/91/65: 18; TKU/A/91/67: 10). Uuestisündinu on täiesti «uus loodu» (2 Kr 5: 17), kes on Hagini järgi ka igal alal hakkama saav ja edukas sellepärast, et uuestisündimisel võtab inimene vastu Jeesuse ja samaaegselt ütleb lahti Saatana valitsusest (Hagin 1993: 18). Patt ja haigus kõrvaldatakse ning päästmine ja tervis tulevad asemele, kui tuginetakse Jeesuse lepitustööle ristisurma läbi. Pöördumisest kõneldes seletas üks intervjueeritav mõistet järgmiselt, öeldes lahti kõigest sellest, mida oli esindanud enne oma pöördumist:

See tähendab seda, et ma olen täiesti uus. Sellega, et ma sain usklikuks ja võtsin Jeesuse vastu, olen ma saand täiesti uueks. Et see sisemine inimene, kes ma olin varem, see on nii nagu minevik. Et need kõik, mu vanad süüteod ja soga ja muu, mis ma olen teind vana inimesena nagu selle kombel, nii et neid ei ole enam. Ma olen nagu uus loodu Jeesuses Kristuses, ja Jeesuse veri on mind puhtaks teind. Jah, nii see on. (TKU/A/91/68: 29).

Idee sel viisil puhastavast uuestisündimisest põhineb arusaamal, et inimene koosneb kolmest osast, milleks on vaim, hing ja ihu. Uuestisündimine toimub nimelt vaimus. Vaim on inimese õige, sisim mina, hinges paiknevad mõistus, tunne ja tahe. Hinge valdkonnal pole midagi tegemist Jumalaga ja sellepärast ei suuda hing mõista vaimulikke asju. Mõistus on inimestele antud inimliku elu jaoks (ES 5). Ainult vaim võib mõista Piiblit. Seetõttu näiteks mõistusega - mis ju kuulub hinge alla - mõeldes võib Piiblist leida vastuolulist ja sellest arusaamine on problemaatiline. Keha ei muutu pöördumises ja just sellepärast ongi inimestel probleeme «lihaga». Uuestisündimist nähakse protsessina, mis tugevneb aste-astmelt; kuigi vai- 
mus toimuvad muutused, ei muutu hing ja keha vältimatult samas taktis, näiteks jäävad paljud asjad «hinge peale vaevama» või inimene langeb kehaliste kiusatuste tõttu. Vaimu uuestisündimise välise tagajärjena saab inimene Usuliikumise õpetuse järgi siiski õiguse ka füüsilisele tervisele ja üliküllusele elus. Uskliku elus domineerib vaim hinge ja keha üle (Hambre et al. 1985: 62-64; ES 2, ES 3).

Hagin kirjeldab oma nooruses toimunud tervenemisprotsessi nagu eeskuju usu kaudu tervenemiseks. Õpetus on selles, et inimene ei või oma vaevadest paraneda, kui tal on vale usk, kui ta viljeleb kaotusmeeleolu ja alistub olukordadele. Sel juhul takistab Saatana ülemvõim inimese tervenemist ja edukust (Hagin 1993: 25-26). Ekman osutab edasi seda, et Jumal soovib tervendada kõiki ja kasutab näitena Jeesuse tegevust.Ta täpsustab, et tervenemine ei tarvitse siiski vältimatult toimuda hetke jooksul ja et inimene ei tohi muutuda hulljulgeks. Arstid ja ravimidki on tema järgi osa Jumala tööriistadest samal viisil kui näiteks armuannid, kasvõi usupalve. Arstid ja ravimid «võitlevad sama vaenlase vastu» (Ekman 1985: 77, 84).

Edu toob ainult õige usk õigetesse asjadesse. Hagin viitab (terminoloogilise paradoksina) «vaimulikule arukusele», mille all ta mõtleb usaldust Piibli lubaduste vastu (Hagin 1993: 24). Probleemide lahendamine on siiski inimese enda vastutusel, ta saab ise teha oma valiku (nagu Aadam paradiisis). Inimene ei tohi näiteks olla hoolimatu ja pillaja, vaid tuleb olla arukas ja pidada oma rahaasjadki hästi korras (Ekman 1992: 73; ES 1; ES 2; ES 3). Kurjale tuleb vastu hakata, püüdes lahti saada halisemismentaliteedist ja abitusest ning asjatutest hirmudest. Usklik ei tohi olla «negatiivselt programmeeritud» ja karta, kuna see kõigutab usku ja toetab niiviisi kuradi tööd (Hagin 1993: 28-32). Usk ei tohi olla vaid usk millessegi, vaid meetod, «Jumala usk» (vt Mk 11: 22). Kristlane võib öelda, mida ta endale soovib, ja saada selle. Tagajärg sünnib sõna jõust. Usu vahend on palve ja usklikul palujal on õigus saada positiivne vastus (Hambre et al. 1985: 66). See seadus kehtib mitte ainult elu suurte otsustuste suhtes, vaid ka argielu pisiasjade kohta (TKU/A/91/68: 25; ES 2; ES 5).

Ulf Ekman on viimistlenud Usuliikumise õpetusi veel konkreetsemale tasemele, kõneldes väga igapäevastest ja traditsiooniliselt «mitteusulistest» asjadest nagu majandus, inimsuhted, seks ja muud argielu määravad realiteedid. Kuna nimelt Usuliikumise suhe rahasse on olnud poleemikat äratav vaidlusküsimus, keskendun suuremalt jaolt sellele osale Ekmani laiaulatuslikust ja mitmeplaanilisest õpetuskirjandusest. Ekmani meelest on «piibellik tõde majanduslikust üliküllusest» olnud varjatud inimliku mõtlemise ja usuliste traditsioonide tõttu, samuti ka sellepärast, et kuri võitleb piibelliku tõe vastu. Oma õpetuse alusena esitab Ekman väite, et Jumal tunneb huvi kõigi eluvaldkondade vastu ja sellepärast on lasknud esile tulla jutlustajaid, kes annavad õpetusi näiteks majanduse kohta. Ekman õhutab inimesi murdma «oma hirmu raha ees», sest rahas iseenesest pole midagi paha. Probleem on ahnetes ja isekates inimestes enestes. Saatan põhjustab hirmu rahapuuduse ees ja ahnuse, mispeale raha hakkab kontrollima inimest, samal ajal kui asi peaks olema just vastupidi (Ekman 1992: 78). Ekman määratleb ülikülluslikkust järgmiselt:

Üliküllus tähendab seda, et sul on rohkem, kui iseendale tarvis läheb, nii et sa võid anda teistele, et nende vajadused saaksid täidetud. Mõned arvavad, et see tähendab vaid raha ja omandit, kuid see tähendab kogu elu. See tähendab aega, energiat, harrastusi, armastust, tervist, tarkust, teadmisi jne. Jumala ülikülluslik elu haarab kõike, mitte ainult ühte eluala (Ekman 1985: 85).

Raha nähakse niisiis nimelt vahendina evangeeliumi levitamiseks. Kui inimesel pole midagi, siis ta ei või ka midagi anda ja aidata teisi. Inimene peab olema valmis ohverdama evangeliseerimistöö jaoks, kuid samal ajal ta võib uskuda, et saab oma ohvri ühel või teisel kujul 
tagasi (Ekman 1985: 88-89). Ilmutusraamatu kirjeldused lõpuajast ja viimsest kohtust on loomulikult kristliku sõnumi kesksemaid teemasid. Nendeks hetkedeks valmistutaksegi ka Elu Sõnas jõulise misjoni- ja evangeliseerimistööga, eesmärgiks päästa võimalikult rohkem inimesi hukatusest. Raha korjamine ja usklike rikastumine ei ole niisiis omaette eesmärk, vaid kasum on vaja "panna paljunema», saamaks sõnumit levitada nii laialt kui võimalik. Käsitlen hiljem, seoses koguduse tegutsemise ülevaatega, liikumise liikmete misjonikohustust lähemalt.

Ekman selgitab, et on vale mõista õnnistust ainult vaimuliku asjana ja mitte sugugi materiaalsena. Sellise seisukohani on tema arvates jõutud seetõttu, et on järgitud liiaks kreeka filosoofiat, kus vaimne ja materiaalne on eraldatud teineteise vastanditeks. Vaimulik on siiski kõik see, mis tuleb Jumalalt, sest Jumal on vaim (Ekman 1992: 18). Ekman kasutab näitena Aabrahami Vanast Testamendist. Aabraham tegi lepingu Jumalaga. Ta loovutas oma tulust Jumalale kümnist ja sellepärast õnnistati teda rikkusega. Selle looga põhjendatakse ka andmise tähtsust (Ekman 1992: 45).

Rikkus ja üliküllus tähendab siiski rohkem kui pelgalt raha või maist rikkust. Kui inimene on egoistlik ja tahab rikkust iseendale, siis rikastumine ei õnnestu. Kui taas inimese hoiak on õige, siis tegutseb Jumal ka sel materiaalsel alal. Õige hoiak on valmidus loobuda. Kristlane ei pea küll kõigest loobuma, kuid peab olema valmis vajaduse korral andma. Ekmani järgi tasub loobumine alati ära, sest selle saab sajakordselt tagasi (Ekman 1992: 64-69). Õpetuses ohverdamise ja kümnise maksmise kohta kõneldakse külvamisest ja lõikamisest. Tagasi saab alati sama liiki, mida on külvatud, kuigi idanemine võib võtta oma aja. Ekmani meelest räägib Paulus 2. kirjas korintlastele oma ohvrikõnes nimelt rahast. Külvates ei vaesuta, vaid rikastutakse, samuti juhtub evangeliseerimistööga, et see ulatuks üle kogu maailma (Ekman 1985: 89-90; Ekman 1992: 93-97). Majanduslik edugi on niisiis põhimõtteliselt seotud püüdega päästa ehk ümber pöörata lõpuaegade saabumiseks kogu maailm.

\section{Elämän Sana (Elu Sõna) tegevus}

Soomes rajati Elu Sõna Turus 26.8.1990. Rajamishetkel liitus koguduseks umbes 40 liiget. Juba varem tegutseti siiski nii Helsingis kui Turus, kus sel ajal käis koosolekuid pidamas pastor Håkan Westergård Uppsalast. Alguses olid need vaid 7-8 inimese palverühmad, mis vahel laienesid ligi paarisaja osavõtjaga koosolekuteks. Oma Turusse rajatud kogudust iseloomustaski Westergård «Livets Ord'i töö istandikuks». Sidemed Uppsalaga on jätkuvalt tihedad, kuigi Turu Elämän Sana on täiesti iseseisev kogudus samasugusest nimest

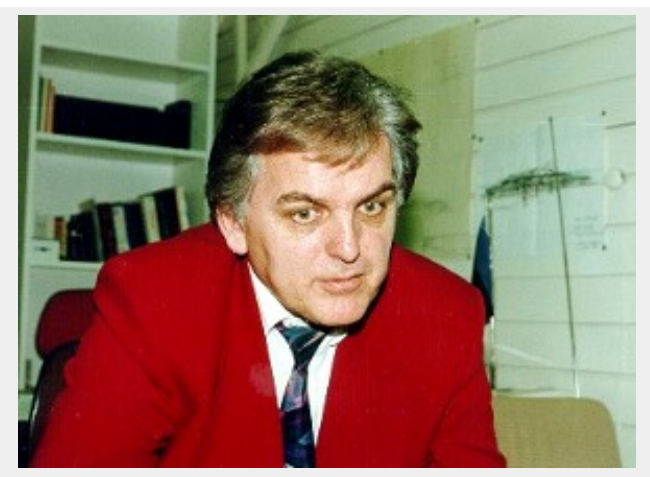

Håkan Westergård, Turu Elu Sõna koguduse pastor hoolimata. Elämän Sana on veendunud, et see, mis toimib Rootsis, ei toimi vältimatult Soomes, nii et tegevus on omaalgatuslik. ${ }^{7}$ Sidemeid hoitakse siiski, eriti jutlustajate külaskäikude vormis, ja paljud Elämän Sana liikmed on käinud Livets Ord'i piiblikoolis. Suurematel evangeliseerimisüritustel ehk konverentsidel käiakse vastastikku külas (ES 1, ES 3; ES 5; TKU/A/91/67: 9-11).

Elämän Sana ruumid on Turu kesklinnas ja tegevust on rohkesti. Pühapäeviti on koguduse saalis umbes 2-3 tunni pikkune jumalateenistus, mille järel peetakse kohvikut nii, et koosolekule tulijad saavad üksteist kohata ja suhelda. Kolmapäeviti on õpetamisvormiline koos- 
olek Focus - Jumala sõna tulipunktis (ES 3). Igal teisel reedeõhtul sisustatakse kogudusesaal linnas liikuvate noorte jaoks Night Café'ks. Koguduse noorte tegevuse hoolekandjate Elina ja Jonathan Westergårdi järgi käib öökohvikus tavaliselt 200-300 noort õhtu jooksul. Kliendid kuuluvad kooliealiste hulka. Kohvi ja küpsetiste kõrval pakutakse ka programmi, nagu kristliku päästmisteemaga kooskõlas olevaid omaloomingulisi lühinäidendeid, või on kohale kutsutud noori huvitavaid kõnelejaid. Night Café tegevuse lähtekohaks on põhimõte «noortelt noortele». Oma idee sütitajaks peab Jonathan Westergård erinevate koguduste teetubasid, mis aga tegutsesid väikese võimsusega ja pakkusid huvi vaid käputäiele noortele. 1993. aastal alustanud Night Café eesmärk oligi saada ühendust laiema noorsoohulgaga väljaspool kogudust. Night Café's ei tohi suitsetada ega alkoholi juua - pudelid jäetakse uksel maha. Purjusolek pole ometi sissepääsule takistuseks, mis teebki õhtud mõnikord üpris sündmusrikkaiks (ES 8).

Koguduses korraldatakse nädala jooksul mitmeid kollektiivseid palvehetki ja esmaspäeva õhtul julgustatakse koguduse liikmeid pidama palvehetki oma kodudes. Kord nädalas palvetatakse koguduses eriliselt Iisraeli eest. Iisraeli-töö on Elämän Sana's nagu muudeski vabakristlikes kogudustes jõuliselt esil. Üheks näiteks on Venemaal tehtav antisemitismi-vastane Operatsioon Jabotinsky, $\underline{\mathbf{8}}$ mille eesmärgiks on aidata Venemaa juutidel Iisraeli rännata (ES 3). Iisraeli eest palvetajad põhjendavad asja sellega, et juudid on Jumala äravalitud rahvas ja Iisrael kristluse algkodu (ES 7). Lisaks nähakse juutide tagasipöördumises üht osa lõpuaegade poole suunatud kavast. Iisraeli kõrval on selgesti esil ka isamaa. ${ }^{2}$ Uppsalas pidasid Livets Ord'i soomlastest liikmed enne koguduse rajamist kodumaal Soome-palveringi, kus palvetati Soome eest, üheks eesmärgiks ka abistajate leidmine Turu kogudusele (TKU/A/91/67: 10). Rahvuslust põhjendab Westergård sellega, et Jumal on andnud inimestele teatud piirid, riigi, mida peab evangeliseerima. Inimesed peavad tundma vastutust oma maa pärast ja olema selle eest tänulikud. On tähtis julgustada soomlasi olema soomlased Euroopa Liidu tingimustest hoolimata.10 Tõsi küll, Euroopa Liidust on see praktiline kasu, et on hõlpsam käia evangeliseerimas (ES 3).

Igal nädalal korraldatakse ka ülistusharjutusi ja evangeliseerimist, nii et programm on väga tihe. Sellepärast rõhutabki Westergård, et ei eeldata iga liikme osalemist kõiges, vaid igaühel tuleb leida endale sobiva osalemise määr. Lisaks korraldab kogudus mitmesuguseid kampaaniaid. Igal aastal korraldatakse suvekonverents, mis on aasta suurim ettevõtmine, ja talvekonverents. Nendele lisaks on veel väiksemaid ettevõtmisi peaaegu igas kuus. Suurematel üritustel on ikka külalisjutlustajaid, kuna see toob õpetusse vaheldust. Kõikidel koosolekutel käib ka kogudusest väljaspool olevaid kuulajaid (ES 3).

Misjonitööd, evangeliseerimist, peetakse niisiis Elämän Sana's tähtsaks kohustuseks. Turu kogudusest on tehtud kaks misjonireisi Ida-Aafrikasse. Tansaanias töötab püsivalt Elämän Sana misjonäridest abielupaar. Venemaa sisemisjon (Ryska Inlands Mission) on olnud Livets Ord'i tööpõlluks juba kümmekond aastat (Heino 1997: 147). Nüüd on Livets Ord varsti valmis laiendama oma misjonitööd ka Indiasse, kus on eesmärgiks avada mitmeid misjonikoole (ES 2). Samuti on Balti riigid olnud tiheda misjonitöö objektideks ja jutlustajad käivad aeg-ajalt külas naabermaade kogudustes. Turu Elämän Sana on korraldanud ühistöös eestlastega näiteks telgikoosolekuid (ES 3).

Soomes tehtavad «tiimimatkad» on samuti osa Elämän Sana koguduse misjonitööst. Sel puhul liiguvad koguduse liikmed väiksemate rühmadena, nii et kaasasolijail on võimalus evangeliseerida ja tunnistada oma kogemusi. Piiblikoolis käinud on nende ülesannetega harjunud. «Tiimimatku» on tehtud eriti Lappeenranda ja mujale Ida-Soomesse, kus Usuliikumisel pole püsivaid tugikohti. Eesmärgiks pole «röövida» liikmeid muudest kohalikest kogudustest, 
vaid pakkuda midagi sellist, mis huvitaks neid inimesi, kes ei ole ühegi koguduse liikmed (ES 4; ES 5; ES 6). Elämän Sana liikmed on oma koguduse ja Usuliikumise esimene täiskasvanute sugupõlv Soomes. Neil on jõuline pioneerivaim ja nad kogevad end elavat ärkamise murranguajal.

Koguduse liikmed on kõik väga motiveeritud oma sõnumi levitamiseks ja ootavad hetke, mil võiksid seda ülesannet tõhusalt täita uutes kohalikes kogudustes üle Soome. Nagu väljendas üks küsitletuist, tõstavad peaaegu kõik käed, kui koosolekul küsitakse: «Kellel on misjonitöö südamel?» (ES 5). Kõik ei soovi tingimata minna välismaale, kuid igaühel on mingi visioon sellest, kuidas võiks ise evangeliseerimistööd edendada.

Elämän Sana piiblikool on Uppsala malli kohaselt tegutsenud Turus neli aastat. Piiblikoolis on mitmeid oma aineid õpetavaid õpetajaid. Kursused vahelduvad aasta-aastalt. Piiblikoolis on siiamaani olnud 10-40 õpilast korraga. Kokku on Turu piiblikooli lõpetanud umbes 100 õpilast (ES 2). Vahendite puudumise tõttu on piiblikool paar aastat «puhanud», kuid 1998. aasta sügisel on kavas õpetust taasalustada. Peaaegu kõik koguduse liikmed on lõpetanud piiblikooli kas Uppsalas või Turus. Seda peetakse isiku vaimuliku arengu seisukohalt olemuslikult tähtsaks (ES 3). Kõik minu poolt intervjueeritud koguduse liikmed on pidanud piiblikooliaastat üheks tähelepanuväärsemaks oma elus. Piiblikool on andnud neile kindlust ja julgust, muuhulgas õpetusega armuandide kasutamisest ja evangeliseerimisest, mida kooliajal praktiliselt harjutatakse majast-majja-meetodil Turu eeslinnades (ES 1; ES 4; ES 5).

Elämän Sana peab ka kristlikku põhikooli. Alguses oli koolis nii alam- kui ülemaste, kuid ülemastmest on loobutud sellepärast, et selle sihipärane ülevalpidamine on kohatult suur majanduslik koormus väikesele kogudusele. Alamastmel on kokku vaid 10 õpilast, kuid see arv kasvab 1998. aasta sügisel. Kristlik põhikool asutati pastor Westergårdi järgi sellepärast, et lastel on õigus kasvada kristlikus õhkkonnas. Murettekitavaks asjaks ühiskonnas peetakse New Age'i vaimu, mis võõrutab inimesed ristiusust. Kool on avatud kõigile, mitte ainult Elämän Sana liikmete lastele (ES 3; ES 8; ES 10; Turkulainen 8.3.1998).

Elämän Sana on sõlminud suhteid muude kohalike vabakogudustega, olles üle saanud algusaegade umbusust ja vastuseisust. Westergårdi järgi «pöördus kirikuajaloos uus lehekülg» 1.4.1998, kui Elämän Sana, nelipühikogudus, vabakirik, baptistikirik ja metodistikirik korraldasid Turus ühisürituse. Tema arvates olnuks see veel paari aasta eest lausa võimatu. Uus äratusliikumine tekitab oma imelike mõtete tõttu ikka kahtlusi ja vastuseisu. Vastuseisu Elämän Sana'le (ja Livets Ord'ile) peab Westergård siiski üpris väikeseks, võrreldes omal ajal baptistide või nelipühilaste kohatud «surmaohuga». Eriti baptistid on tema meelest raadanud teed tulevastele kogudustele (ES 3).

\section{Eesmärgiks edu}

See, miks Elämän Sana vastu on ka Soomes kriitikat suunatud, eriti muude kristlike ühenduste poolt, on johtunud arvamusest, et Elämän Sana esindab Soomes uueks ja võõraks peetud nõndanimetatud eduteoloogiat. Kiriku uurimiskeskuse juhataja Harri Heino iseloomustas eduteoloogiat mõtteviisina, mille kohaselt Jumala tahe on, et iga inimene saaks juba selles elus jumaliku tervise ja heaolu ja võiks usu kaudu elada võidukat elu igal alal (Heino 1997: 147). Mõte pole päris uus Soomeski. 1950. aastail latter rain-äratusliikumine nelipühiringkondades rõhutas edu tähtsust Jumala õnnistusena. Ka lestadiuslusse kuulub mõte õnnistustest maise rikkuse vormis. $\underline{\underline{11}}$

Eduteoloogiat on kritiseeritud nii evangeelse luterliku kiriku kui muude vabakoguduste poolt, kuid ka väljastpoolt usuühinguid. $\underline{\mathbf{1 2}}$ Elämän Sana liikmed jutustavad, et on sageli näiteks 
turul evangeliseerides sattunud vastaja ossa. Üldine arusaam kogudusest on olnud see, et liikmeskond koosneb valdavalt hästi toimetulevaist ja jõukaist keskklassi edukatest, kelle eesmärgiks on senisest veelgi rikkamaks saada. Tegelikult on märkimisväärne osa koguduse liikmeist siiski ülioopilased ja noored täiskasvanud, paljud ajutistel või osa-ajalistel töökohtadel või töötud (ES 6; ES 7; ES 3). Kuigi Livets Ord'i rajaja Ulf Ekman õpetabki uskliku õigust heaolule, juhib ta ometi tähelepanu sellele, et majanduselu on ikkagi ülikülluse kõige madalam vorm (Ekman 1992: 99). Edasi jälgin lähemalt eduteoloogia lähtekohti, raha ja usu suhet ning edu mõistet individuaaltasandil, Elämän Sana liikmete kogetuna.

\section{Eduteoloogia juured}

Rootsi uurijaterühm Christer Hambre et al. paigutab eduteoloogia juured Ameerika Ühendriikide varasesse kirikulukku. Ameerika teoloogiat valitses reformeeritud puritaanlik traditsioon. Põhisuundadeks olid eriti kalvinism, puritanism ja metodism. Kalvinism siirdus 18. sajandil Euroopast Ameerika religioossele maastikule presbüterliku kirikuna. Peamiseks põhimõtteks oli, et Jumal on kõikvõimas ja et Piiblist, eriti Vanast Testamendist, saab ammutada juhtnööre kõigi elualade kohta nii majanduses kui ühiskonnaelus ja poliitikas. Usklik pidi usinalt tööd tegema ja elama vähenõudlikku elu kollektiivis. Materiaalset edu peeti kindlaks märgiks Jumala soosingus olemisest. Puritanismi eesmärgiks tema algkodus Inglismaal oli anglikaani kiriku puhastamine katolitsismi mõjudest. Ameerikas ühines puritanism presbüterlike kirikutega ja, nagu kalvinismiski, oli mõtteviisiks Piibli, eriti Vana Testamendi pidamine ühiskondliku elu juhtnööriks. Vanast Testamendist lähtus ka mõte rikkusest ja heaolust kui Jumala soosingu märkidest. Usin töö ja säästlikkus lõid põhja kapitalismile롱 (Hambre et al. 1985: 26-27).

Puritaanid nõudsid, et kirikut võivad juhtida ainult uuestisündinud. See hoogustas ka metodismi esiletulekut 1770. aastail, nimelt holiness-liikumisena, mis omakorda rajas aluse nelipühilisusele. Kalvinismi karm predestinatsiooniõpetus hakkas taanduma inimese enese päästmisvastutuse teelt. Anglikaani pastori John Wesley pühitsusmeetodiks oli pühade kirjutiste õppimine ja õpetuste rakendamine praktilises elus. Ka metodism tuli emigrantidega koos Ameerikasse ja pani seal toime tähelepanuvärse äratuse. Erijooneks oli arusaam pühitsusest, eesmärgiks saavutada täiuslikkus, nii et inimene võiks Jumala tahte vastaselt toimida vaid teadmatult. Niisiis oli liikumistes ühesuguseid jooni, mis liitusid 19.-20. sajandil ameerikalikuks eduteoloogiaks. Need ühisjooned olid näiteks täiustumisideaal, range ja eetiline eluviis (Hambre et al. 1985: 27-28).

Reformeeritud kristluse protest rajanes põhimõtteil, mis panidki aluse eduteoloogiale Ameerikas. Esimeseks põhimõtteks oli kirjasõna autoriteet. Jumalasõna on algne tõde, mille sõnumit lunastusest on hämardanud katoliku kiriku sakramendiõpetus. Teiseks räägiti jutlustes usu läbi õigeksmõistmisest. Usu all mõeldi usaldust Jeesuse vastu ja õigeksmõistmise all päästmiskindlust. Kolmandaks põhimõtteks oli usklike preesterlus. Protestandid tõid individualismiidee kollektiivsesse jumalateenistusse, väites, et igal usklikul üksikisikul on võimalus individuaalseks jumalasuhteks. Neljandaks põhimõtteks oli kirik, mis pidi teenima pühade osadusena. Rõhutati jutlustamist, õpetamist. Oldi arvamusel, et usklikel on õigus kuulata Sõna ning jõuda selgusele, mida see tähendab, selle asemel et jumalateenistus oleks põhinenud pelgalt sakramentidel. Individuaalsuse kaasamine pakkus ilmikuilegi neid pühitsusvõimalusi, mis olid kuulunud ainult munkadele ja nunnadele (Albanese 1992: 103-105).

Suhtumine töösse kujunes teistsuguseks, sest reformatsioon viljeles moraalipõhimõtet, et inimene ei tohi olla jõude, vaid peab andma tunnistust oma usust tegude kaudu (Albanese 1992: 105). Ühendriikides on varaste immigrantide vajaduste kohaseks vormitud kristlusel 
olnud suurem tähendus maapealse elu valitsemise kui igavikuküsimuste jaoks. Kuulutustöös on esiplaanil olnud väärtused, millest on saanud WASP14 - keskklassi kaubamärk. Edukus, tõhusus, turvalisus ja vabadus elu eesmärkidena on suunanud kristluse pragmaatilisse, optimistlikku, aktiivsesse ja individualistlikku suunda. Eesmärgiks on olnud saada ellu rõõmu ja jõudu, mis praktiliselt vaadates eeldab ka tervist ja heaolu (Hambre et al. 1985: 34).

Tervendamisäratuse esindajate järgi olid negatiivsed mõtted ja väär usk patud. Mõtted väidetakse iseendid teostavat. Mõteldes õigesti, positiivselt, võib inimene saada kõike head nagu tervist, vabadust, edu. Paljud neist mõtetest on saanud alguse mind cure ideoloogiast, $1 \underline{15}$ näiteks Christian Science -suunast (Hambre et al. 1985: 35). Norman Vincent Peale on üks tuntumaid eduteoloogia väljakujundajaid, kelle mõtteviisis võib näha jooni mind cure-filosoofiast edu-siin-ja-praegu-põhimõttena (vt nt Peale 1984). Peale'i ideoloogilised juured on The Gospel of Wealth ja mind cure-liikumistes. Tema kirjalik toodang on laiaulatuslik ja valgustab paljude näidete varal edule viiva mõtteviisi meetodit.

Hambre et al. on analüüsinud tervet hulka kristlike eduõpikute autoreid ja täheldanud, et nad esindavad kahte suunda. Positiivse mõtlemise liin rõhutab inimese vaimset tervist ja välist edu. Seda liini esindavad näiteks just Norman Vincent Peale ning Yonggi Cho, LõunaKoreas tegutseva maailma suurima nelipühikoguduse pastor, kelle õpetustega on tutvunud ka paljud Elämän Sana liikmed (ja kelle ühe teose nime olen oma pealkirjas tsiteerinud). Teiseks suunaks on uurimisrühm lugenud kirjanduse, milles käsitletakse rohkem inimeste vaimset poolt ja tuginetakse rohketele piiblitsitaatidele. Sellesse rühma asetavad nad muuhulgas Kenneth E. Hagini (Hambre et al. 1985). Ulf Ekmanit peetakse Kenneth E. Hagini õpilaseks, kes on siiranud selle õpetuse Livets Ord'i. Hagin keskendub siiski oma raamatus «Õige ja väär mõtlemine» vaimsele ja vaimulikule poolele - mõtlemisele, millele on ehitatud kogu tegevus. Ekman taas pigem ühendab kahe eelmainitud suuna strateegiaid. Ta kõneleb maise heaolu õigustatusest ja põhjendab seda Piibli fundamentalistliku tõlgendamisega. Niisiis ei korda Ekman otse Hagini õpetust, vaid on arendanud sellest oma eduteoloogia.

\section{Kas kõneldakse sellest, millest puudust tuntakse?}

Uusi usuliikumisi arvustatakse kergesti rahale omistatud tähtsuse pärast. Nad ei naudi üldist tunnustust ühiskonnas, mistõttu peavad ise oma majandusasjade eest hoolitsema. Kogudused kulutavad märkimisväärselt palju aega rahakorjamiseks, mis tõuseb silmatorkavalt esile võrdluses valitseva kirikuga, kus see probleem on lahendatud «peenetundelisemalt». Sageli maksavad inimesed, kes kritiseerivad valitsevast kirikust väljapoole jäävate usuühingute tegevust, oma eluaja jooksul kirikumaksu rohkem kui uue usuliikumise läbilõikeliige (Rothstein 1997: 310). Kõik kaasaja ühiskonnas tegutsevad organisatsioonid on sunnitud rahaga tegemist tegema. Avalik tegevus lihtsalt maksab. Sellest hoolimata tahetakse nimelt uusi usuliikumisi meelsamini näha kristlikku või budistlikku vaesusideaali järgivat - usklikul arvatakse vaja minevat ainult toitu ja riideid (Rothstein 1997: 305-306).

Paljud uued usuliikumised tegelevadki - näilikult oma ideaalide vastaselt - laialt organiseeritud ettevõtlusega. Sellistest ülemaailmsetest religioossetest majandusorganisatsioonidest nimetagem näiteks ülemaailmse toetuse osaliseks saanud Unification Church'i ehk Ühinemiskirikut ja Isckon'i ehk Krishna-teadvus-liikumist. Usuühing, kes soovib toimida liberaalses ja kapitalistlikus ümbruses tõhusalt ja ekspansiivselt, peab mingil määral kohanema selle tingimustega (Rothstein 1997: 311-314). Seni, kuni liikumised toimivad seaduse piires, ei või nende tegevust kritiseerida. Taani uususundite uurija Mikael Rothstein tõdebki lakooniliselt, et usuliikumistele osaks langev sallimatus on ülekohtune seni, kuni kapitalism ja parempoolne poliitika pole ühiskonnas keelatud (Rothstein 1997: 316). 
Raha on realiteet, ilma milleta on raske, kui mitte võimatu, toimida kaasaja ühiskonnas. Ka usulised nagu mistahes muud ühingud vajavad seda, tulemaks toime argirutiiniga, nagu üüri, kütte, valgustuse eest maksmine, samuti infolevi korraldamine (Rothstein 1997: 309). Lehekuulutused ja tänaval jagatavate traktaatide trükkimine on ülesanded, mida ilma rahata ei saa täita. Suurim osa koguduse tegevusest põhineb vabatahtlikul tööl. Näiteks maksab Night Café ülalpidamine kogudusele vaid umbes 300 marka õhtu kohta, sest kogu töö tehakse talgu korras. Elämän Sana ülesandeks on «päästesõnumi» levitamine, võimalikult tõhus ja laiaulatuslik misjonitöö, mille organiseerimine neelab nii palju raha, kui selleks antakse. Pastori sooviks on tõsta väljaspool Soomet tehtava misjonitöö eelarvet 10 protsendini koguduse käibest (ES 3).

Nii Elämän Sana kui muude vabade kristlike suundade tegevuse rahastamine põhineb liikumise õpetusel usklike ohvreist ja kümnisest, kindlaid liikmemakse ei ole (ES 3). Eespool seletasin Ulf Ekmani käsitust majandusest ja rahakasutusest, külvamise ja lõikamise põhimõttest. Seda arusaama järgitakse Elämän Sana's nõnda, et liikmed annavad oma tulust kümnist või niipalju, kui arvavad võivat anda. Kümnis korjatakse kord kuus koguduse pühapäevasel jumalateenistusel nii, et oma raha võib anda suletud nimeta kirjaümbrikus korjandusastjasse. Nõnda kontrollib andja ise andmist. Ohvreid õhutatakse andma ka eriotstarveteks, nagu kampaaniad ja misjonitöö eri paigus. Väljaspool seisjad peavad kümnise ja ohvrite andmist sageli ülekohtuseks raha kasseerimiseks, kuid tõsiasi on seegi, et usuühingute liikmed säästavad teiselt poolt suuri summasid, loobudes paljudest asjadest, nagu alkoholi tarvitamisest ja tubakast, või tunnistades tarbetuks moe orjaliku järgimise.

Ühingusse investeerimine võib ka kõrgendada isiku hindamist ühingu piires. See on teistele märk sellest, et isik austab ideoloogiat ja oma rühma enam kui ilmalikku ümbrust. Teiselt poolt võib olukorda näha ka lihtsama kaubana: liikumine müüb, isik ostab! (Rothstein 1997: 307-308). Võidakse ju pakkuda kasvõi erikursusi, mille abil isik võib saavutada esoteerilisi oskusi (vrd näiteks saientoloogia hierarhiliselt kumuleeruvad kursused, vt nt Heino 1997: 314), või tuleviku kaitstus, nagu pääsemine viimsete aegade õudustest. Näiteks nimetavad Elämän Sana piiblikooli lõpetanud seda sageli just «investeeringuks», tasuvaks paigutuseks, millest on kasu kogu ülejäänud eluks. Piiblikooli on sageli investeeritud muudki kui pelgalt raha. Selles seotakse end aastaks ajaks vähemalt viieks hommikupoolseks päevaks nädalas, nii et paljud jutustavad end olevat jätnud turvalise töökoha ja korteri ning loobunud endistest inimsuhetest, et saada kinnitust oma usule (nt ES 1; ES 4; ES 5; ES 7; ES 9; ES 10).

\section{Edu argipool}

Õpetuskirjandus ja ehk jutlusedki, mille eesmärk on julgustada ja orienteerida koguduse liikmeid soovitud suunda, annavad kiire tutvumise tulemusena üpris ühemõõtmelise pildi liikumise ideoloogiast: usklikul on õigus paluda ja ta saab soovitu automaatselt. Eduteoloogia kritiseerijate arusaamad põhinevad sageli just põhimõttelisele tasandile ehitatud õpetuskirjandusel, kus ideoloogia põhikohti seletatakse teravdatult, või koguni infokanalite sensatsioonihimulistel uudistel. Kui religioosses kollektiivis kõneldakse rahast, saavad välispidised kergesti mulje, et seal muust ei kõneldagi (ES 3). Raha on nii soome traditsioonilistes äratusliikumistes kui kirikuski olnud pigem tabu kui keskne aine - on ju kaamelilgi kergem pääseda läbi nõelasilma kui rikkal taevariiki.

Rahast, autodest, korteritest ja muudest konkreetsetest argielusse kuuluvaist «maistest asjadest» tõepoolest kõneldakse Elämän Sana's avameelselt, nende asjade eest isegi palvetatakse. Elämän Sana liikmete eneste arusaam mõistest 'eduteoloogia' on kahesugune. See tekitab nalja ja nördimust, kuid teiselt poolt ei peeta seda päris valekski, sest lõpuks soovi- 
vad ju kõik edu, nii koguduse liikmed kui kogudusest väljaspool seisvad inimesed. Üpris kiiresti muutub Elämän Sana liikmetega vesteldes küsitavaks eduteoloogia kui lihtsameelne arusaam sellest, kuidas Jumal autasustab usklikke eriti rahaliste õnnistustega ja hea tervisega. Praktikas ja üksikisiku tasandil on asi märgatavalt varjundirikkam.

Kuidas siis väljaspool äratuskoosolekuid saadakse aru eduteoloogiast, kujutelmast Jumala ja Saatana mõjude kohta inimese elus? Kuigi liikumise tekstid ja jutlused jätavad sellest mulje kui mehhaanilisest rikkakssaamise tehnikast, on rahavood üksikliikme kohta suhteliselt tagasihoidlikud. Raha andmine kogudusele ohvrina Jeesusele paneb väljaspoolse ennast kergesti ebamugavalt tundma, kuid usklikule tagab see tähtsaima asja maailmas - onnnistuse. Ohvri mõte on säilitada argielus tasakaal hea ja halva vahel, püsida lähemal Jumalale kui Saatanale. Üksnes kriitilistel hetkedel ohverdamine hädast väljapääsemiseks poleks Ekmani järgi õige ohverdamine. Ülemäärase äraandmine peab olema normaalne käitumine (Ekman 1985: 89-90). Võib mõelda, et ajutine rahapuudus või haigestumine on suur probleem, kuid neid võib mõista ka ainult «Saatana rünnakutena», mille eesmärgiks on panna usklik kõikuma. Aktiivne osalemine koguduse õpetustöös siiski suunab usklikku mõtlema «raskete olukordade» üle ja usaldama tulevikku (ES 1; ES 2; ES 4; ES 6; ES 9). Elusõnalasele ei tähendagi «edu» või «õnnistus» sama, mis väljaspoolsele. Väikestki kasu võidakse kogeda suure õnnistusena. Usklik on sisestanud positiivsete võimaluste ja asjade tähelepanemise ja ta suhtub hoolimatult või tõrjuvalt negatiivsesse tagasisidesse.

Minu intervjueeritud Elämän Sana liikmed on kirjeldanud edu enda elus mitmel viisil. Edu on üks õnnistuse vormidest. See võib ilmneda mistahes elualal, peale rahaliste õnnistuste ka tervisena (või tervenemisena), vaimuliku kasvamisena või aktiivse ühiskondliku eluna. Isiklikud edujutustused puudutavad abikaasa leidmist (ES 1; ES 7; ES 8), korteri leidmist (ES 1; ES 10; ES 4; ES 5), töökoha leidmist (ES 1; ES 2; ES 4; ES 5; TKU/A/91/66; ES 7; ES 9) ja seeläbi üldist elukvaliteedi paranemist. Nende edukogemuste lähtekohaks on igal juhtumil pöördumine, uuestisünnikogemus. Selle järel on elu läinud teise suunda ja muutusi nähakse ühemõtteliselt headena. Uue tähendussüsteemi rajamine on siis konkreetselt ehitanud ka kõiki normaalse inimelu tahke. Õnnistust ja edu kogetakse ka kõige väiksemais asjus. Kõik intervjueeritavad märgivad, et Jumal kannab hoolt ka pisiasjade eest, üksikjuhtumite eest. Õnnistusena kirjeldatakse näiteks raha saamist sõidukulude katteks, vana sõbra kohtamist, sobivate riiete leidmist kauplusest jne.

Edu määrangut argielus võib usundipsühholoogia terminites iseloomustada atributiseerimisprotsessina, tähenduse andmisena õigeks tõlgendusmudeliks peetud taustraami põhjal. Bernard Spilka et al. järgi motiveerib atributiseerimist 16 kolm elementi. Esiteks on inimesel tarve tunda sündmusi tähenduslikena. Samuti on tal tarve ennustada ja kontrollida sündmusi ning vajadus kaitsta, säilitada ja tugevdada minapilti ja iseteadlikkust. Niisiis suunavad religioosset kogemust individuaalsed tarbed, seesmised vajadused, nagu uurijad neid nimetavad (Spilka et al. 1985: 3; 1995: 428). Terminiga 'seesmised vajadused' viidatakse tuntud ja palju kasutatud religioosse orientatsiooni kahemõõtmelisele tüpoloogiale, mis on loodud laiaulatuslike küsitluste alusel. Välispidine orientatsioon on utilitaarne, kasule sihitud ja instrumentaalne, kuna seesmiselt orienteeritud inimene on sisestanud oma usu ja nii-öelda elab seda. Tüpoloogia kritiseerijad on korduvalt esile toonud seiga, et need orientatsioonid ei ole üksteist välistavad, vaid osalt paralleelsed. Kogu religioossus pürib mingisuguse kasu saavutamise poole - olgu selles või teispoolses elus -, mida on tahetud mõista välispidise hoiakuna, instrumentaalse suhtumisena religiooni. Seesmine religioossus «elatud usuna» sisaldab ju ka oma kasumõtte. Ka sügavalt seesmiselt orienteeritud inimene võib oma usku näha argielu aspektist mitmel viisil kasulikuna. Kahemõõtmelist religioossuse tüpoloogiat 
on kritiseeritud kui piisamatut, kuna kristliku ainestiku najal arendatuna see ei näi väljaspool kristlust toimivat (Wulff 1991: 235; Batson et al. 1992: 164-165). $\frac{17}{}$ Minu arusaama kohaselt see ei toimi eriti veenvalt ka ristiusu piires, mis puutub kristluse tegelikesse ja rahvapärasematesse vormidesse väljaspool valitsevat kirikut.

\section{Lõpetuseks}

Edu on ikka soovitud ja seda on otsitud religioonide, okultismi ja profaansete toimingute abil. Edu ja selle taotlemine mitmesuguste püüete ja pingutuste kaudu on iseenesest kõikide religioonide olemuslik osa (ka rahvausundis on elatusalade edukus keskne teema, vrd näiteks kratiusku või arusaamu karjaõnne suurendamisest, rikkumisest jne. $\underline{\underline{18}}$

Ulatuslik õpetuskirjandus tundub võrsuvat peamiselt rasketest aegadest. Ka ilmalike eduõpikute kerkimine Soome müügiedetabelite tippu saab alguse üheksakümnendate alguse majanduslikust madalseisust, mille tagajärgede all paljud jätkuvalt kannatavad. Analoogiliselt avaldas ilmalike eduõpikute klassik Dale Carnegie oma teose «Kuidas võita sõpru ja mõjutada inimesi?» 1930. aastatel, kui Ameerika ühiskonna majanduselu libises allamäge. Ka kristlik eduteoloogia on ajalooliselt seotud Ameerika immigrantide ellujäämisstrateegiatega aegadel, mil toimetulemine ja ühiskondliku elu tingimused polnud enesestmõistetavused. Ka tervendamisäratuse järele oli sõjajärgses ühiskonnas nõudmine. Kristliku usu ja argielu profaansete taotluste segu on kõige selgemini väljendatud reformeeritud kristluse ameerikalikus vormis.

Ameerika kristlusest võrsunud Livets Ord sündis Rootsis majandusliku madalseisu ajal ja on Mikael Rothsteini meelest just oma ajale tüüpiline liikumine: selles rõhutatakse kasvu, väärtuse tõusu, individuaalset panustamist ja luuakse paljulubavaid ning lohutavaid tulevikuvisioone, nagu uutes usuliikumistes üldiseltki. Need ju ongi vastused aja väljakutsetele ja inimese tarvetele. Livets Ord tõestab taas kord kristluse kohandumist ajastuomaste tingimustega. Ta on ühendanud Lääne kapitalismiga usulised tõotused (Rothstein 1997: 317). Õige usk viib heasse ellu, mis tagab ka rahalise turvalisuse, raha on õnnistus, märk Jumala soosingust.

Sellegipärast tajutakse eduteoloogia-nimetust Elämän Sana's halvakspanevana ja eksitavana. See jätab mulje, nagu oleks edu midagi suurt ja sensatsioonilist ning koguduse liikmetele automaatselt osaks langevat. Niisugusesse edusse Elämän Sana liikmed ei usu. Sellest hoolimata olen kasutanud käesolevas artiklis eduteoloogia mõistet, üritades neutraalsel toonil selgitada selle juuri ja kasutamisseoseid ning tähele panna ka Elämän Sana liikmete endi nägemusi asja kohta. Eduteoloogiast kõnelevadki need uurijad, kes on uurinud eduõpetajate kirjatöid. Teadagi esitatakse neis mõtteid väga põhimõttelisel tasandil ja lihtsustavalt. Argielu uurimisel kollektiivi liikmete kogemuste kaudu manifesteeruvad need õpetused igapäevaelus paljudel erinevatel viisidel. Kui uurija suunab oma luubi argielu poole, muutub käsitus edust otsustavalt teistsuguseks. Tahtmatult tuleb tõdeda, et see pole lainetavate rahavoogude vastuvõtmine ja lakkamatu pidu, vaid et küsimus on hakkamasaamises, selles, et pääseda terve nahaga argipäeva käest ning et haigusest või rahapuudusest ei kujuneks inimest muserdavat probleemi, vaid et tal oleks võime sellest üle saada või kohaneda sellega elama.

Edu määratlemine on lõpuks teadussotsioloogiline ja metodoloogiline küsimus. Teadmine ja kogemus edust kujuneb vältimatult mingist kontekstist lähtudes, see on suhteline. Juba kahe intervjuu järel sai selgeks, et «eduteoloogia» väljaspoolsete antud nimetusena ei vasta kollektiivi liikmete eneste vastavale kogemusele. See nimetus ilmutab ühelt poolt valitseva kiriku teoloogilist ja teiselt poolt profaanset vaatenurka, mis takerduvad ühte silmapaistvasse, valitsevast religioossusest kõrvale kalduvasse omadusse, omadusse, mida kollektiivi 
liikmed peavad «kõrvaltooteks», kuid mida aus olles ei saa ka eitada. Unelmate auto või raha on detailid, mis on mingisuguses suhtes liikme usklikuks saamisega ja kõige muuga, mida ta usus läbi elab.

Humanistlikult orienteeritud (usundi)antropoloogia ei tohi ühte omadusse takerduda ja tõlgendada seda enda vaatenurgast, näiteks selle kaudu konstrueerides kollektiivile «eetost» (nagu edu, uhke auto, rikkana paistmine), ja samal ajal sulgeda silmi kõige muu ees, mida kõneleb empiiriline ainestik, kollektiivi liikmete jutud. Kelle uskumusi siis lõpuks uuritakse, kas uurija või uuritavate omi?모 Usuliikumine on emic-mõiste, mis intervjueeritavate, niisiis siseringi kuulujate meelest üldhõlmavana näitab paremini, milles on küsimus. Eduteoloogia on etic-mõiste ehk liikumisest väljaspool seisjate antud nimetus, akadeemilistes uurimustes (nt Hambre et al. 1985) siiski neutraalsena kasutatud mõiste. Juhul kui etic-mõisted tuleks täiesti vande alla panna, siis peab tõdema, et kohusetruu antropoloog ei saaks sel juhul kõnelda ka «religioonist», kuna see esindab uuritavate meelest «kombekristlust» ja välispidist «religioossust» ja mitte seda, mida nad ise kogevad, «usku» ja «usus elamist».

Eduõpikute järele on jätkuvalt nõudmist sellest hoolimata, et ideed ja teemad esitatakse kõigis neis pisut erinevate nimede all, sõltuvalt kirjutaja taustast. Inimene peab pidevalt arenema ja enesesse uskuma (nagu Peale ütleb: «...tea, mida sa soovid, ja usu, et suudad selle saada» - Peale 1984: 314). Tuleb olla eesmärgiteadlik ja virk. Kuna inimene on psühhofüüsiline olend, siis võib ta ennast terveks mõtelda. Hea kumuleerub. Isegi ärialal töötavaile inimestele kirjutatud õpperaamatus viidatakse Matteuse evangeeliumi (Matteuse 25) tähendamissõnale sulaste talentidest õpetliku näitena usinuse ja taiplikkuse kasulikkusest (Airisto 1996: 280-281). Ilmekas on ka Soomes praegusel hetkel tuntuima eluviisiõpetaja Jari Sarasvuo poolt väärtuskasvatuse sekka heidetud tõdemus: «[---] kui väärtuste järjestus on laitmatu, siis mida halba on selles, kui taskupõhja koguneb ka muud peale puru» (Sarasvuo 1996: 294). See pole kaugel Ulf Ekmani mõtetest. Hagin räägib - nagu ka Sarasvuo - mõtteviisi muutumisest. Väsimus ja oskamatus on vaid eksitus ja keskkonna (või Saatana) püüded meid murda (Sarasvuo 1996: 19; Hagin 1993: 25).

Sõltumata eduõpiku taustast, olgu see siis kristlik või ilmalik, leidub kõigis õpikuis samu tõdesid, üldkehtivaid tervele mõistusele põhinevaid seaduspärasusi, mille varal inimesed on oma ümbruskonnaga toime tulnud aastatuhandete vältel - ja saavutanud edu. Õpikute laia spektrisse kuulub ka teatud iroonia: inimesed igatsevad edu saavutada otseteed mööda, hõlpsaid võtteid kasutades. Keeldutakse nägemast edukate vaevanägemist või ohvreid ja kinnitatakse tähelepanu ainult sellele, mis on saavutatud. Õpperaamatuist hangitakse trikke, mis viivad kiire ja vaevatu tulemuseni. Irooniline on see, et kõigis õpetusraamatuis märgitakse kõva töö, plaanipärasuse, tervislike eluviiside, enda eest hoolitsemise ja murdumatuse, «usus püsimise» põhimõtteid. Teadagi suudavad vaid vähesed neid süstemaatiliselt järgida. Kõikide eduõpikute järgi tuleb olla valmis tooma «ohvreid», et saada «õnnistusi». Seda õpetust teostavad Elämän Sana liikmed igapäevaselt teadlikult piiblikoolist saadud varustusega. 


\section{Kirjandus}

Airisto, Lenita 1996. Menestys! Uusia näkemyksiä ja selkeitä virikkeitä 2000-luvun

businessihmiselle. Helsinki: Otava.

Albanese, Catherine L. 1992. America. Religions and Religion. Belmont: Wadsworth Publishing

Company.

Batson, C. Daniel \& Patricia Schoenrade \& W. Larry Ventis 1993. Religion and the individual. A social-psychological perspective. New York: Oxford University Press.

Coleman, Simon 1993. Conservative Protestantism and the World Order: The Faith Movement in the United States and Sweden. Sociology of Religion 54: 4, 353-373.

Ekman, Ulf 1985. Usko joka voittaa maailman. Älvsjö: Uusi Elämä. (Tro som övervinner världen. Uppsala: Livets Ords Förlag. 1985).

Ekman, Ulf 1992. Taloudellinen vapaus. Helsinki: Uskon Sanan kustannus Oy. (Ekonomisk frihet. Uppsala: Livets Ords Förlag. 1989).

Gustavsson, Anders 1991. Vanan, synden och världen i väckelsemiljöer. Om tron och vardagslivets ordning. Jonas Frykman \& Orvar Löfgren (red.). Svenska vanor och ovanor. Stockholm: Natur och kultur, lk 198-219.

Hagin, Kenneth E. 1993. Oikea ja väärä ajattelu. Helsinki: Uskon Sanan kustannus Oy. (Right and Wrong Thinking. Tulsa: Kenneth Hagin Ministries, Inc. 1986).

Hambre, Christian et al. 1983. Framgångsteologi. En analys och prövning. Stockholm: EFS

förlaget.

Harrell, David Edwin, Jr. 1975. All Things Are Possible. The Healing \& Charismatic Revivals in Modern America. Bloomington: Indiana University Press.

Heelas, Paul 1996. The New Age Movement. The Celebration of the Self and the Sacralization of Modernity. Oxford: Balckwell Publishers.

Heino, Harri 1997. Mihin Suomi tänään uskoo. Porvoo: WSOY.

Holm, Nils G. 1976. Tungotal och andedop. En religionpsykologisk undersökning av glossolali hos finlandssvenska pingstvänner. (Acta universitatis Upsaliensis. Psychologia Religionum 5.) Uppsala. Holm, Nils G. 1978. Pingströrelsen. En religionsvetenskaplig studie av pigströrelsen $i$

Svenskfinland. Meddelanden från Stiftelsen för Åbo Akademi forskningsinstitut, nr 31. Åbo.

Hufford, David J. 1983. The Supernatural and the Sociology of Knowledge: Explaining Academic

Belief. New York Folklore 9, lk 3-4.

Junnonaho, Martti 1996. Uudet uskonnot - vastakulttuuria ja vaihtoehtoja. Tutkimus TM-, DLM- ja Hare Krishna -liikkeistä suomalaisessa uskonmaisemassa. Helsinki: Suomalaisen Kirjallisuuden Seura.

Lawless, Elaine J. 1988. «The Night I Got the Holy Ghost...» Holy Ghost Narratives and the Pentecostal Conversion Process. Western Folklore 47, 1k 1-20.

Lupfer, Michael B. \& Karla F. Brock \& Stephen J. DePaola 1992. The Use of Secular and Religious Attributions to Explain Everyday Behavior. Journal for the Scientific Study of Religion 31(4), 1k 486-503.

Lupfer, Michael B. \& Donna Tolliver \& Mark Jackson 1996. Explaining Life-Altering Occurences: A Test of the 'God-of-the-Gaps' Hypothesis. Journal for the Scientific Study of Religion 35(4), lk 379-391.

McGuire, Meredith 1981. Religion: the Social Context. Belmont: Wadsworth.

McGuire, Meredith 1988. Ritual Healing in Suburban America. New Brunswick: Rutgers University Press.

McGuire, Meredith 1992. Religion: The Social Context. Belmont: Wadsworth.<

Peale, Norman Vincent 1984. Sen teet mihin uskot. Hämeenlinna: Arvi A. Karisto Oy. (You Can If You Think You Can. Englewood Cliffs: Prentice-Hall, Inc. 1974). 
Rothstein, Mikael 1997. Gud är blå. De nya religiösa rörelserna. Nora: Bokförlaget Nya Doxa. (Gud er blå. De nye religiøse bevægelser. Køpenhavn: Gyldendals Forlag. 1991).

Samarin, William J. 1972. Tongues of Men and Angels. The Religious Language of Pentecostalism. New York: The Macmillan Company.

Sarasvuo, Jari 1996. Sisäinen sankari. Helsinki: WSOY.

Spilka, Bernard \& Daniel N. McIntosh 1995. Attribution theory and religious experience. Ralph W. Hood Jr. (ed.). Handbook of religious experience. Birmingham: Religious education press, 1k 421445.

Spilka, Bernard, Phillip Shaver \& Lee A. Kirkpatrick 1985. A general attribution theory for the psychology of religion. Journal for the scientific study of religion 24(1), lk 1-20.

Wulff, David M. 1991. Psychology of religion. Classic and contemporary views. New York: John Wiley \& Sons.

\section{Ajalehed}

Christianity Today 1993, 37:14. Elämän Sanan seurakunnan Uutislehti. Kevät/kesä 1998. HS = Helsingin Sanomat 9.1.1992.Helsingin Sanomat 4.12.1994.

Helsingin Sanomat 27.3.1996.

Turkulainen 8.3.1998.

\section{Intervjuud:}

Elämän Sana (ES) koguduse liikmete intervjuud aastatel 1991 (TKU-arhiiv, Turu Ülikool) ja 1998 (autori valduses).

\section{Kommentaarid}

* Artikkel põhineb peamiselt minu poolt Turu Elämän Sana koguduses aastail 1991 ja 1998 tehtud intervjuudel.

1. Teoloog Raija Sollamo, osaledes ajalehes Helsingin Sanomat peetud mõttevahetuses religioosse fundamentalismi üle, iseloomustas seda kokkuvõtlikult kui usklike kommet pidada oma pühakirja eksimatuks tõeks kõigis ajaloolistes olukordades ja kõigis oludes, pööramata tähelepanu tekstiseostele, kultuurikeskkonnale ja muutunud olukordadele ning uutele teadmistele ja kogemustele (HS 27.3.1996).

2. Püha Vaimuga ristimiseks peetakse olukorda, mil inimest arvatakse esmakordselt täituvat Püha Vaimuga ja saavat niimoodi otsese osaduse Jumalaga. Selle sündmuse tunnusmärgiks on võõraste keelte rääkimine ehk glossolaalia. Nelipühiliikumises, kus Püha Vaimuga ristimine on võetud just õpetuse keskseks teemaks vastavalt Piibli Apostlite tegude raamatus kirjeldatud nelipühasündmusele (vt Ap 2: 1-20), rõhutatakse vaimuristimise taotlemise tähtsust ja selle võimalikkust kõigile soovijaile. (Võõraste keelte rääkimisest vt nt Samarin 1972; Holm 1976; Lawless 1988). 
3. Meredith McGuire on selgesti kirjeldanud karismaatilise kristluse sisimat ideed haigustest ja hädadest ning nende paranemisest hierarhiliste üleloomulike jõudude, Jumala ja Saatana tegevusväljana. Jumala tervendavat jõudu arvatakse sageli vahendatavat teise inimese kaudu, kes kasutab parandamiseks Jumala väega täidetud sõnu või esemeid, kasvõi palverätikut. Saatanat arvatakse jälle takistavat paranemist, tugevdades patu mõju inimese elus ja lahutades inimest Jumalast (McGuire 1988: 55-57).

4. Jutlustaja all mõeldakse tavaliselt teatud koguduses püsivalt mõju avaldavat juhtivat kuju, pastorit, kuna taas nimetus evangelist osutab iseseisvalt tegutsevat, erinevates kogudustes külalisena esinevat, rändavat õpetajat. Oklahomalane Oral Roberts on kuulsaim Teise maailmasõja järgne tervendamisäratuse evangelist (Harrell 1975: 19).

5. William F. (Billy) Graham (snd 1918) võttis evangeliseerimistöös kasutusele moodsa tehnika. Alates aastast 1947 kasutas ta raadiot, TV-d ja filmi, soovitades inimestel teha usuvalikuid. Graham ühendas oma kuulutuses evangeelset konservatismi ja natsionalistlikku poliitikat ning kujundas need teemad millennaristlikuks lõpuaja sõnumiks (Albanese 1992: 159-160).

6. Ameerika usutervendaja stereotüübiks oli kaua Burt Lancasteri esitatud tegelaskuju filmist «Petturjutlustaja» (Elmer Gantry 1960, rezhissöör Richard Brooks, USA). Film kirjeldas vaesele rahvale korraldatud vaatemängulisi telgikoosolekuid, milles kontsentreerus kaootiline lootus paremast tulevikust. Teemaks oli ahnuse, pettuse, kuritarvitamise ja showbisnise seosed tervendamisäratusega. Kõnealune film lõi äratuse imagole raskeid haavu, mida karismaatilised äratajad on üritanud parandada (Harrell 1975: 4). Hiljem käsitleti sedasama imedega rahategemise teemat 1980-ndate aastate kontekstis filmis «Usupuudus» (Leap of Faith, 1992, rezhissöör Richard Pearce, USA), milles Steve Martin mängis väikestes kohtades ringi rändava rühma evangelisti. Mõlemaid filme võib vaadelda oma ajajärguga seotud karismaatiliste äratusliikumiste sarkastilise kriitikana.

7. Uppsala Livets Ord'i teostatud ameerikaliku ja rootsiliku religioossuse, kultuuri ja ühiskondliku tegevuse ühendamise kohta vt Coleman 1993.

8. Livets Ord'i operatsioon on saanud oma nime Jabotinsky-nimelise mehe järgi, kes 1930. aastail reisis mööda Euroopat ja hoiatas juute peatselt algavate tagakiusamiste eest (ES 3: 28).

9. Uppsala Livets Ord'is viljeldakse mõtet rahvuse eripärast ja Jumala väljavalituks olemisest. Rootsit peetakse eriliselt õnnistatuks maaks selle jõukuse tõttu ja sellepärast, et tal on olnud üpris tähtis osa Euroopa ajaloos oma rahvaarvu suhtelisest väiksusest hoolimata (Coleman 1993: 359).

10.Euroopa Liidu tulekut peeti 1989-1990. aastate vahetusel Põhjamaade vabakristlikes liikumistes Ilmutusraamatu ennustuste täitumiseks, mitmepealiseks lõpuaegade elajaks (TKU/A/91/67: 19). Näiteks Norra EL-mõttevahetuses pidasid selle ägedaimad vastased, usulised ringkonnad, Liitu uuestisündinud saatanaks. «Ei ole sugugi juhus, et Euroopa Liidu asutamislepingut kutsutakse Rooma lepinguks - Ilmutusraamatus ennustati, et Rooma järeltulija on mitmepealine koletis» (HS 9.1.1992). Kirikusotsioloog Tapio Lampinen kirjutas oma veerus, et äärmusprotestantlikud rühmad on alati armastanud seda kujutelma. Seda on üha uuesti rakendatud ajakohaste nähtuste suhtes. Lampise järgi «Käesoleval [20.] sajandil on koletiseks olnud igatahes Hitler, Stalin, Nõukogude Liit, kommunism ja EL. Paavst on sageli liidetud nägemusse koletise valeprohvetina: Antikristusena» (HS 4.12.1994). 
11.1995. aastal avastatud majanduskuritegude puhul tuli ilmsiks lestadiuslastest ettevõtjate suur osakaal. Asja seletati lestadiuslaste väärtusmaailma abil, mille kohaselt ilmaliku edukuse märgid tõstavad üksikisiku ja pere mainet lestadiuslaste ühenduses ja on samal ajal märgid Jumala soosingust (nt Harri Nykänen, HS 19.4.1995).

12.Usuliikumise eduteoloogia vastu on suunatud tugevat kriitikat ka selle sünnipaigas Ameerikas, kus muud kristlikud suunad peavad Usuliikumise vastu teoloogilist võitlust õige piiblitõlgenduse nimel (vt nt Hank Hanegraaf 1993. Christianity in Crisis. Harvest House). $\mathrm{Ka}$ internet on erinevate teoloogiliste seisukohtade avaldamise paik, vt nt http://www.agape7.com/cult/wfaith.htm (viidatud 31.7.1998).

13.Sotsioloog Max Weber sidus selle mõtte teodiike-probleemiga ehk religioosse seletusega ühiskonnas ebavõrdselt jaotuvate eesõiguste ja kannatuste kohta. Heaolu võidakse õigustada, pidades seda märgiks jumalapoolsest heakskiitvast hoiakust inimese töökuse ja moraalse eluviisi suhtes (McGuire 1992: 192). Teoses Protestantlik eetika ja kapitalismi vaim on Weber rajanud nägemuse protestantlike (nt kalvinism, puritaanlus) voolude maailmakesksest asketismist, mille abil on üheaegselt püritud vaimuliku päästmise ja parema ühiskondlikmajandusliku staatuse poole. Raha ei tohi niisiis raisata tühisuse peale, vaid peab elama säästlikult ja tegema virgalt tööd (McGuire 1992: 199-200).

14. White Anglo-Saxon Protestant (Valge anglo-saksi protestant).

15.Mind cure-mõtlemise sünniaeg on 19. sajandi algus. Keskne idee oli, et inimene peab püüdma mõtelda Jumala mõtteid. Erinevus puritaanlusest on selles, et kui puritaanid rõhutasid Jumala tahte tähtsust, siis mind cure ei pooldanud mõtet Jumala meelevaldsest tahtest. Samuti ei võtnud mind cure seisukohta teispoolsusega seotud küsimustes. Iga inimene võib saada Jumalalt siin ja praegu kõik, mida ta soovib. See, et Jumal täidaks inimese soovid, eeldab siiski, et ta oleks puhas ja vooruslik. Mind cure ei üritanud ka protestantide kombel parandada keskkonda, näiteks ehitades koole vms, vaid oli sihitud pigem indiviidi privaatse vaimse arengu poole. (Nt Donald Meyer 1980 (1965). The Positive Thinkers. Religion as Pop Psychology from Mary Baker to Oral Roberts. New York: Pantheon Books).

16.Bernard Spilka, Phillip Shaver, Lee A. Kirkpatric ja Daniel N. McIntosh on rajanud usundipsühholoogilise teooria tähenduse andmisest atributsioonina, protsessina, milles uus asi liigendatakse olemasoleva tähendussüsteemi kategooriatesse. Atribuutsiooniteooriat on kohaldatud nii argikontekstis kui ka elu muutvate kogemuste analüüsimiseks (vt nt Lupfer et al. 1992 ja Lupfer et al. 1996).

17.Seespidine-välispidine -tüpoloogias Batson et al. kirjeldavad kolmest malli usklikkuse mõõtmiseks: usk vahendina (vastab välispidisele tüübile), eesmärgina (vastab seespidisele tüübile) ja otsimisena. Usku kui otsimist esindavad näiteks sellised religioossed autoriteedid nagu Siddhartha Gautama, Malcolm X või Mahatma Gandhi, kes otsivad lakkamatult viimset tõtt, seades kahtluse alla etteantud tõdesid. Kuna seda usklikkuse-tüüpi Elu Sõnas tegelikult ei soovita, siis ei käsitle ma siin kolmemõõtmelist usklikkuse tüpoloogiat.

18.Uno Harva 1928. Para. Vertaileva tutkimus. Turun yliopiston julkaisuja. Sarja B, osa VII. Üldisemalt soome-ugri rahvaste usundite seosest elatusalade ja sotsiaalsete rollidega vt nt Lauri Honko 1987. Finno-Ugric Religions. The Encyclopedia of Religions 5, 334. 
19.1997. aasta sügisel olid minu poolt kohatud Uppsala usundiloolased sügavalt vapustatud ja mures Livets Ord'i majandamispõhimõtete pärast. Nad panid pahaks koguduse rahakorjamist ja pidasid seda peaaegu varjatud kuritegevuseks. Sellist arusaama on ilmselt kohalik meedia jõuliselt õhutanud. Teadusliku mõtlemise vältimatuks osaks ja uurimise objektiivsuse eelduseks peetakse negatiivset ja skeptilist - iseenesest hinnatavat - hoiakut. See hoiak tugevneb kergesti veelgi, kui uurimisobjektiks on uurija ratsionaalsusest väljapoole jäävad uskumused (vrd Hufford 1983: 24-25). 